\title{
Observations of cetaceans off southern Sri Lanka, April 2007-2013
}

\author{
R.C. ANDERSON ${ }^{1}$ AND A. AlagiyaWAdU ${ }^{2}$
}

Contacte-mails: anderson@dhivehinet.net.mv; charles.anderson11@btinternet.com

\begin{abstract}
Cetaceans were observed off the South coast of Sri Lanka in the month of April, every year over a seven-year period, 2007-13. During 48 days at sea a total of 290 cetacean sightings were recorded. Blue whales were abundant, accounting for $61 \%(n=177)$ of all sightings. This concentration of blue whales was predicted and discovered based on a migration hypothesis and there was evidence of the expected net westward movement in April. Nevertheless, most blue whales seen were not obviously on passage and many appeared to be feeding. Mothers with calves and likely reproductive behaviour (breaching and rushing) were also observed. There were five sightings of Bryde's-type whales (B. brydei/edeni); four were identified as $B$. brydei, one was identified as $B$. edeni. Sperm whales were sighted 16 times within a narrow band centred just outside the $1,000 \mathrm{~m}$ isobath. Modal group size was 10-12; based on size most individuals appeared to be mature females or immatures. Spinner dolphin ( $n=35$ sightings) was the most abundant species, accounting for $67 \%$ of all cetaceans seen by number of individuals. They were frequently associated with tuna and seabirds. Risso's dolphin was only seen once, despite being reported as common around Sri Lanka in the early 1980s. They were taken in large numbers by local fisheries, which may have reduced local abundance. Other species recorded were: dwarf sperm whale $(n=3$ sightings); shortfinned pilot whale $(n=3)$; common bottlenose dolphin $(n=9)$; Indo-Pacific bottlenose dolphin $(n=3)$; pantropical spotted dolphin $(n=4)$; and striped dolphin $(n=4)$. Since the discovery of blue whales off southern Sri Lanka, commercial whale watching centred on the fishing port of Mirissa has developed rapidly, bringing new revenue to the region but also the potential for disturbance to the whales.
\end{abstract}

KEYWORDS: BLUE WHALE; BRYDE'S WHALE; COMMON BOTTLENOSE DOLPHIN; DWARF SPERM WHALE; INCIDENTAL CATCHES; INDIAN OCEAN; INDO-PACIFIC BOTTLENOSE DOLPHIN; MIGRATION; PAN-TROPICAL SPOTTED DOLPHIN; RISSO'S DOLPHIN; SANCTUARIES; SCHOOL SIZE; SHORT-FINNED PILOT WHALE; STRIPED DOLPHIN; WHALE WATCHING

\section{INTRODUCTION}

Blue whales in the northern Indian Ocean are believed to belong to a distinct subspecies, Balaenoptera musculus indica Blyth, 1859 (Perrin et al., 2010; Anderson et al., 2012). These whales have been known to occur around Sri Lanka for well over a century (Blyth, 1859; Fernando, 1912). Deraniyagala (1948) even characterised blue whales as 'common off Ceylon' (Sri Lanka). However, during the mid-1960s Soviet whalers took 1,294 blue whales from the Arabian Sea, including waters that are now part of the Exclusive Economic Zone (EEZ) of Sri Lanka (Berzin, 2008; Brownell, 1995; Clapham and Ivashchenko, 2009; Mikhalev, 1996; Mikhalev, 2000; Yablokov, 1994). Those Soviet catches were illegal and unreported at the time, and greatly reduced the northern Indian Ocean blue whale population, perhaps to just $10 \%$ of its original size (Zemsky and Sazhinov, 1994).

In 1979 the International Whaling Commission (IWC) established the Indian Ocean Sanctuary (IOS). One outcome was the sponsoring, by the World Wildlife Fund (WWF, Netherlands), of an expedition to the IOS to conduct nonlethal cetacean research. That research was carried out from the yacht Tulip, and resulted in a wealth of new information (e.g. Alling, 1986; Alling et al., 1991; Gordon, 1987; 1991). One finding was blue whales off the northeast coast of Sri Lanka near Trincomalee during January-April 1983 and 1984. This came as a surprise at the time (Whitehead, 1983; 1989), perhaps in part because the reduction in whale numbers by Soviet whaling may have contributed to a complete dearth of contemporary reports of blue whales from the region.
Later, a review of cetacean strandings in the neighbouring Maldives (roughly 400 n.miles, $750 \mathrm{~km}$, West of Sri Lanka) confirmed that blue whales strand year-round on the coasts of South Asia (India, Sri Lanka and the Maldives) (Anderson et al., 1999). That review also demonstrated that most strandings occurred during the northeast monsoon season (December to March: see Methods for an outline of the monsoon seasons). Where blue whales went during the southwest monsoon (May to October) was unknown, but it was suggested that many might be feeding in the highly productive seasonal upwellings of the western Arabian Sea (Anderson et al., 1999). Anderson (2005) subsequently demonstrated that sightings of blue whales in the Maldives were also seasonal (occurring during November to April), and again suggested that at least some of the blue whales which were known (from the Tulip research) to spend the early part of each year off northeast Sri Lanka might also feed off Somalia and Arabia in May-October. If this were the case, then it was predicted that those whales should pass eastwards from the Maldives to southern Sri Lanka in about December, returning westwards in April.

On the South coast of Sri Lanka, April tends to bring better weather than December, so a visit was planned for April 2005 to test this prediction. Inspection of Admiralty charts of Sri Lanka showed that Dondra Head was a likely site from which to look for blue whales, not only because it is the island's southernmost point but also because a minor canyon just offshore brings deep water to within about $5 \mathrm{~km}$ of the coast. The visit was postponed for two years following the devastating tsunami of December 2004. 
Dondra Head was finally visited on 18 April 2007. Looking out to sea with a telescope, the first blue whale blow was spotted after just 12 mins of searching. Further observations of blows and whales showing their flukes followed, with at least three blue whales in view. A second visit the next day produced a first blue whale blow within just $10 \mathrm{mins}$, and recorded a minimum of four animals in less than two hours of watching. Following the success of these land-based observations, observations were continued using boat-based surveys. Some findings on blue whales have been reported by Anderson et al. (2012). This paper reports additional cetacean observations from visits during April in seven years, 2007-2013.

\section{METHODS}

\section{Survey area}

The survey area was initially selected as the waters off Dondra Head, the southernmost point of Sri Lanka (Fig. 1). The nearest port to Dondra Head at which a charter boat was available in April 2007 was Mirissa (approximately $15 \mathrm{~km}$ West). Subsequently all boat-based surveys were conducted from there. The edge of the continental shelf lies approximately $7-8 \mathrm{~km}$ South of Mirissa and runs roughly East-West. The continental slope curves northwards South of Dondra Head forming a submarine canyon, the head of which lies about $5 \mathrm{~km}$ offshore (Fig. 1). Much shipping passes around the South coast of Sri Lanka, indeed this is one of the busiest shipping routes in the world, and a traffic separation scheme is in force (Hydrographic Office, 2007). Nearest to the coast is an inshore traffic zone, then a westbound shipping lane (centred around $5^{\circ} 48.5^{\prime} \mathrm{N}$ ), and furthest offshore an eastbound shipping lane (centred around $\left.5^{\circ} 42.5^{\prime} \mathrm{N}\right)$ (Fig. 2).

The meteorology of Sri Lanka (and this study site) is dominated by the monsoons (Fein and Stephens, 1989; Pant

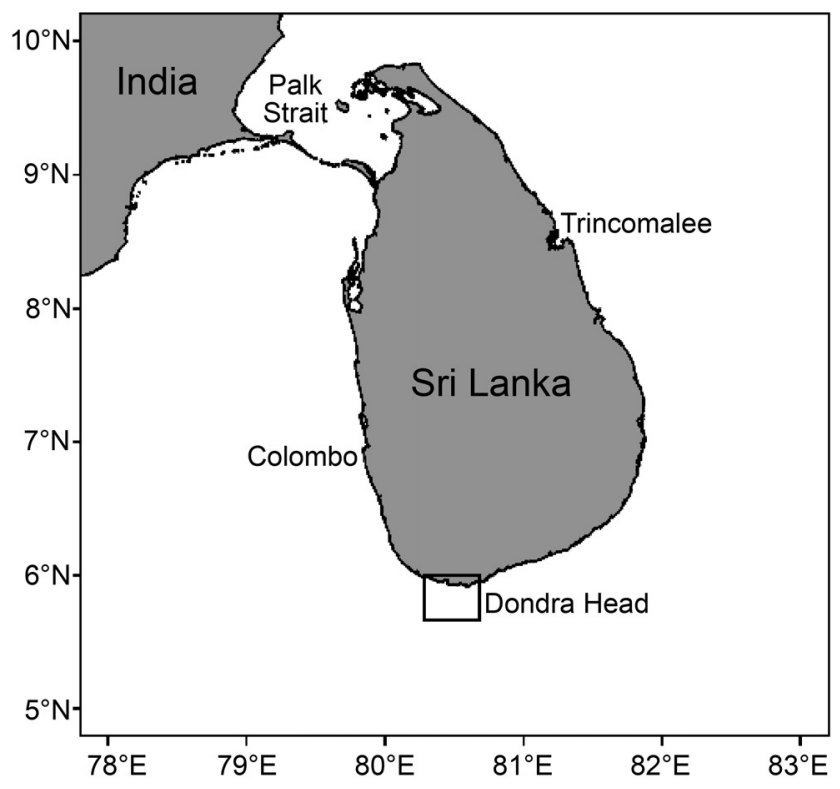

Fig. 1. Location map (the South coast study area is outlined by the rectangular box).

and Kumar, 1997). During the southwest (SW or boreal summer) monsoon, winds are predominantly southwesterly or westerly, blowing from over the Arabian Sea. During the northeast (NE or boreal winter) monsoon, winds are predominantly northeasterly, blowing off the Bay of Bengal. Winds in the northeast monsoon are generally lighter than those of the southwest monsoon. Furthermore, Mirissa is sheltered from northeast winds, but fully exposed to those from the southwest. The southwest monsoon blows from about May to October (although the later months are less windy, and sometimes referred to as the post-monsoon). The northeast monsoon lasts from about December to March. April is an inter-monsoon month, when winds are generally

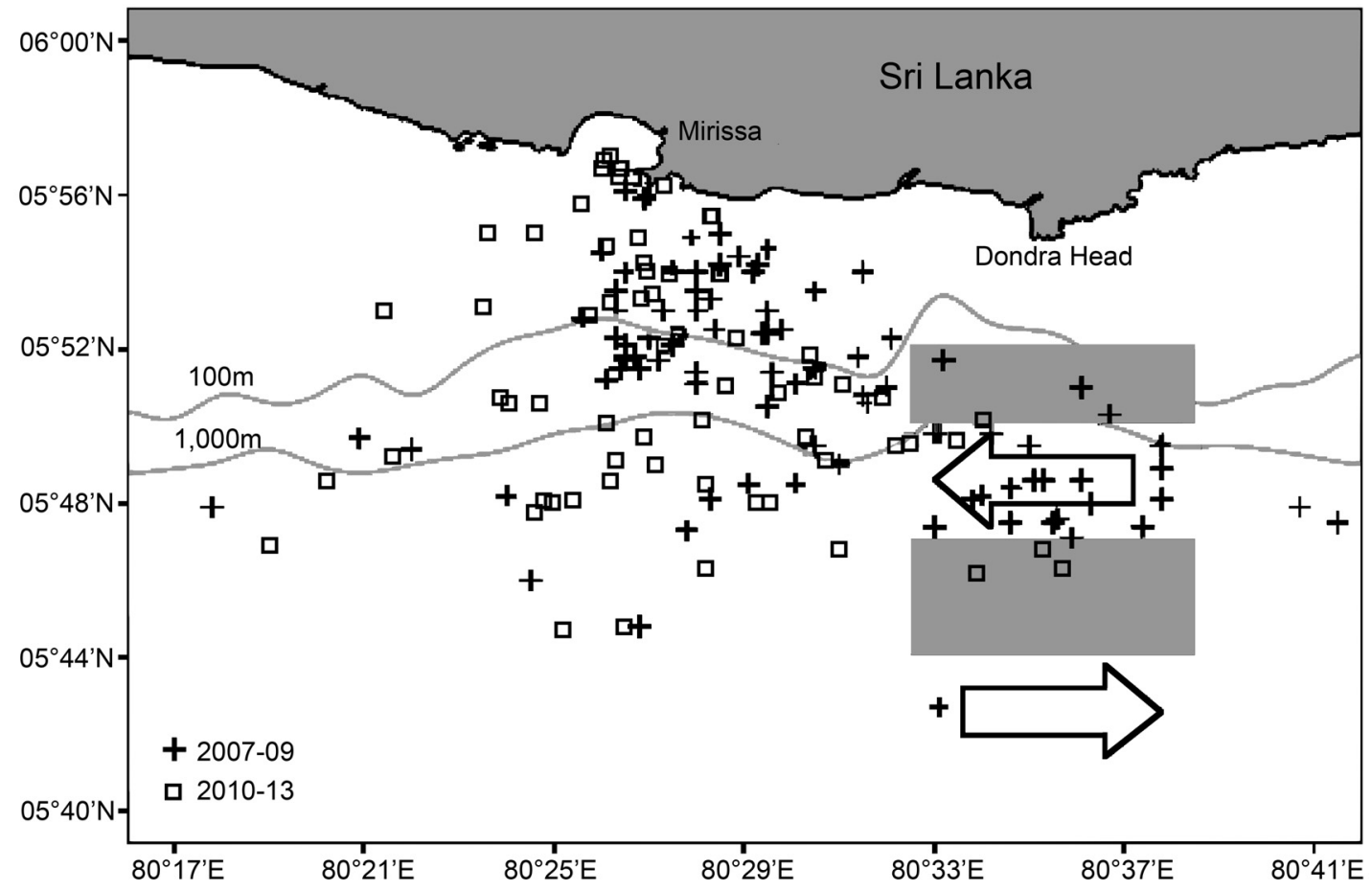

Fig. 2. Distribution of sightings effort off the South coast of Sri Lanka (the markers show 2-hourly boat positions, the grey blocks denote shipping separation zones, while arrows denote shipping lanes). Scale: 4' latitude $=4 \mathrm{n} . \mathrm{miles}=7.4 \mathrm{~km}$. 
light and variable, although the southwest monsoon has usually set in by the end of the month. In addition to the prevailing monsoon winds, strong sea breezes develop on many days. As a result, April sea conditions are usually relatively calm in the mornings, but often become rough by midday or early afternoon.

The oceanography of this site is strongly affected by the seasonally reversing monsoon winds (Wyrtki, 1973; Molinari et al., 1990; Schott and McCreary, 2001; Shankar et al., 2002; Hydrographic Office, 2007; de Vos et al., 2014a). During the southwest monsoon, the Southwest (or Summer or Indian) Monsoon Current flows eastwards past the South of Sri Lanka from the Arabian Sea into the Bay of Bengal. It is joined by the southward flowing West Indian Coastal Current which passes down the West coast and around the South coast of Sri Lanka. During the northeast monsoon, most currents in the region reverse. The eastward flowing Southwest Monsoon Current is replaced by the westward flowing North Equatorial (or Winter Monsoon) Current. During early April currents can be variable, but are generally eastward by the end of the month, although there may be differences between years ( $c f$ de Vos et al., 2014b).

The longshore flow of these currents produces coastal upwellings, which, together with other physical oceanographic processes, promote primary productivity along the West and South coasts during the southwest monsoon and along the East and South coasts during the northeast monsoon (Krey, 1973; Longhurst, 1998; Vinayachandran and Mathew, 2003; Vinayachandran et al., 2004; 2005; de Vos et al., 2014a). In addition, rivers flowing into the sea along the South coast (including the Nilwala Ganga which enters the sea at Matara, between Dondra Head and Mirissa) bring nutrients into the inshore waters, again promoting primary productivity in this area.

\section{Survey methodology}

Surveys were carried out from the fishing port of Mirissa on the $16 \mathrm{~m}$ motorised vessel Spirit of Dondra, for 2-14 days each April (and the last two days of March in 2009) over seven years, 2007-13 (Table 1). In 2007 and 2008, Spirit of Dondra was operating as a general charter boat; by 2009 it was operating as a whale watching vessel. All trips reported here were operated as whale watching trips, under the direction of the authors. The vessel had an average cruising speed of 7-8kts $\left(13-15 \mathrm{~km} \mathrm{~h}^{-1}\right)$ and a maximum speed of $11 \mathrm{kts}\left(20 \mathrm{~km} \mathrm{~h}^{-1}\right)$. Two to four observers maintained a watch, from both the main deck (eye height about $2 \mathrm{~m}$ above the waterline) and the roof of the wheelhouse (about $3.5 \mathrm{~m}$ ) at all times between leaving and returning to port. A total of 48 days of observation were completed, amounting to some $308 \mathrm{hrs}$ at sea (Table 1). The boat's position was recorded every two hours (at 08:00, 10:00, 12:00, 14:00 and 16:00h); these positions are charted in Fig. 2. During 2007-09, most effort was spent East of Mirissa, towards Dondra Canyon. However, as it became apparent that blue whales were to be found all along the outer shelf and slope, including immediately South of Mirissa, more time was spent in that area during 2010-2013 (Fig. 2). During 2007 and 2008, Spirit of Dondra was the only vessel whale watching in the area; in subsequent years the number of other vessels watching whales each day was recorded.
Table 1

Summary of at-sea cetacean survey effort.

\begin{tabular}{crcrrrr}
\hline Year & \multicolumn{1}{c}{$\begin{array}{c}\text { Start } \\
\text { date }\end{array}$} & $\begin{array}{c}\text { Finish } \\
\text { date }\end{array}$ & $\begin{array}{c}\text { No. } \\
\text { days }\end{array}$ & No. hours & $\begin{array}{c}\text { No. } \\
\text { sightings }\end{array}$ & $\begin{array}{c}\text { Blue whale } \\
\text { sightings }\end{array}$ \\
\hline 2007 & 21 Apr. & 23 Apr. & 2 & $9: 30$ & 13 & 7 \\
2008 & 9 Apr. & 22 Apr. & 14 & $99: 15$ & 95 & 64 \\
2009 & 30 Mar. & 11 Apr. & 12 & $72: 45$ & 69 & 44 \\
2010 & 10 Apr. & 16 Apr. & 6 & $42: 25$ & 30 & 6 \\
2011 & 18 Apr. & 24 Apr. & 5 & $29: 30$ & 37 & 27 \\
2012 & 16 Apr. & 21 Apr. & 5 & $32: 20$ & 33 & 21 \\
2013 & 6 Apr. & 11 Apr. & 4 & $22: 30$ & 13 & 8 \\
Total & 30 Mar. 24 Apr. & $\mathbf{4 8}$ & $\mathbf{3 0 8 : 1 5}$ & $\mathbf{2 9 0}$ & $\mathbf{1 7 7}$ \\
\hline
\end{tabular}

For each cetacean encounter, boat position was recorded (with estimated distance and bearing to the cetacean(s) if not close by), group size estimated, presence of calves noted, and behavioural observations noted (including direction of travel if obvious, and interactions between species). Most cetaceans were approached closely enough to allow identification; in the few instances when this was not possible (e.g. while engaged with other cetaceans or when returning to port) identification was made to the lowest taxonomic level possible. For blue whales, defecations were noted and dive times were recorded. Blue whale dive cycles typically consisted of several short shallow dives and surfacings ending with a strongly arched back (and in most cases raised flukes) prior to a long (and presumably deep) dive. Long dive times were recorded (to the nearest minute) whenever there was little likelihood of confusing animals (due to the presence of multiple whales in the area).

\section{RESULTS AND DISCUSSION}

Species accounts

A total of 12 species were recorded from sightings at sea during 2007-13 (Table 2). Selected accounts of species follow.

\section{Blue whale}

Blue whales (Balaenoptera musculus) were abundant, with 177 sightings (61\% of all sightings) and an estimated 270 individuals recorded. Note that this number included several resightings (on different days) of well-marked individuals, so will overestimate the actual number of animals seen. Nevertheless, the South coast of Sri Lanka is clearly home to a significant population of blue whales, for part of the year at least (Anderson et al., 2012; Ilangakoon, 2012a). The apparent abundance of blue whales was not constant throughout the month. Twice as many were seen in the second half of April as were seen during the first half (Table 3 ). In addition, direction of travel in April was recorded for 33 animals; in the early part of the month equal numbers were heading West and East (1-14 April, 8 v. 8), whereas in the latter part more were heading West than East (15-24 April, 11 v. 6). The numbers are small, but these data are consistent with the hypothesis of blue whales returning westward from the East coast during April (Anderson et al., 2012). Nevertheless, most blue whales were not obviously travelling. Many were diving repeatedly in the same general area, apparently feeding. Many instances of defecation were observed, with bright orange faeces suggesting predation on krill or other crustaceans. 
Table 2

Summary of cetacean sightings by species.

\begin{tabular}{|c|c|c|c|c|c|}
\hline & & \multirow{2}{*}{$\begin{array}{c}\text { No. of } \\
\text { sightings }\end{array}$} & \multirow{2}{*}{$\begin{array}{c}\text { No. of } \\
\text { individuals }\end{array}$} & \multicolumn{2}{|c|}{ Group size } \\
\hline & & & & Mean & Range \\
\hline Blue whale & Balaenoptera musculus & 177 & 270 & 1.6 & $1-14$ \\
\hline Probable blue whale & & 9 & 9 & 1.0 & 1 \\
\hline Bryde's whale & Balaenoptera edeni & 5 & 5 & 1.0 & 1 \\
\hline Sperm whale & Physeter macrocephalus & 16 & 179 & 11.2 & $1-35$ \\
\hline Dwarf sperm whale & Kogia sima & 3 & 9 & 3.0 & $1-6$ \\
\hline Beaked whale & Ziphiidae & 1 & 2 & 2 & - \\
\hline Short-finned pilot whale & Globicephala macrorhynchus & 3 & 120 & 40 & $30-50$ \\
\hline Risso's dolphin & Grampus griseus & 1 & 30 & 30 & - \\
\hline Common bottlenose & Tursiops truncatus & 9 & $727 *$ & 90.6 & $25-200$ \\
\hline Indo-pacific bottlenose & Tursiops aduncus & 3 & 24 & 8.0 & $4-12$ \\
\hline Unidentified bottlenose dolphin & Tursiops sp. & 2 & 11 & 5.5 & $1-10$ \\
\hline Spinner dolphin & Stenella longirostris & 35 & 4,986 & 142 & $6-600$ \\
\hline Spotted dolphin & Stenella attenuata & 4 & 410 & 102 & $40-200$ \\
\hline Striped dolphin & Stenella coeruleoalba & 4 & 198 & 49.5 & $8-150$ \\
\hline Unidentified dolphin & & 14 & 421 & - & - \\
\hline Unidentified whale & & 1 & 1 & - & - \\
\hline Unidentified cetacean & & 3 & 4 & - & - \\
\hline Total & & 290 & 7,406 & & \\
\hline
\end{tabular}

*Note: Includes one distant sighting of at least two individuals, not included in group size estimates

Table 3

Numbers of blue whales seen per day off Mirissa in early and late April.

\begin{tabular}{lcccc}
\hline Period & Mean & $95 \%$ CI & Range & Days \\
\hline 1-14 April & 3.8 & \pm 1.2 & $0-10$ & 24 \\
15-24 April & 7.7 & \pm 2.3 & $2-20$ & 22 \\
\hline
\end{tabular}

Dive times (for presumed deep dives, not shorter breathing sequences) were recorded on 132 occasions from 36 whales. Mean dive time was 11.1 mins, and modal time was 10 $12 \mathrm{mins}$. These dive times are similar to the mean deep dive time of $10.7 \mathrm{mins}$ recorded by de Vos et al. (2013b) in the same area, and may be indicative of foraging depth ( $c f$ Doniol-Valcroze et al., 2011). In contrast, among a (smaller) sample of dive times recorded from blue whales (presumed to be on passage) in the Maldives, dives of 10-11mins were particularly uncommon (Anderson, 2005).

In addition to being a feeding area, Sri Lanka also appears to be a breeding area for blue whales. Eleven mother and calf pairs were noted and there were five instances of activity that appeared indicative of courtship or male competition. Breaching by individual animals was observed during four of these five occasions of presumed courtship, while two animals rushing at the surface side-by-side was observed three times. On one of these occasions spinner dolphins (Stenella longirostris) sped in to ride alongside the blue whales, with some dolphins bowriding in front of them. All of these observations occurred during the period 18-22 April (in three different years). All occurred when relatively large numbers of blue whales were in the area (minimum daily counts 8-20).

The observations of calves and apparent breeding behaviour, and of relatively large numbers of blue whales, suggest that this population might have largely recovered from the effects of whaling in the 1960s. Following Soviet whaling, it was suggested that the northern Indian Ocean blue whale population was reduced to perhaps just $10 \%$ of its original size (Zemsky and Sazhinov, 1994). The Antarctic blue whale population may be increasing at about $7 \%$ per year (Branch et al., 2004). Hypothetically, for northern
Indian Ocean blue whales, assuming a population reduced to $10 \%$ of its original size, and a conservative $5 \%$ rate of population increase since 1967 (when Soviet whaling in the region ceased), then the population may have returned to $100 \%$ (i.e. its original size) by 2015 . These numbers can be debated, but there appear to be many blue whales (certainly many 10s, perhaps low 100s) off Sri Lanka, and it is possible that the population may have recovered from the effects of commercial whaling. Nevertheless, there are now real concerns in this region regarding fisheries interactions and other anthropogenic threats. In particular, blue whales off Mirissa are at risk of ship strikes, especially if disturbance by whale watching vessels displaces some offshore into the shipping lanes (Ilangakoon, 2012c, 2013; Randage et al., 2014; de Vos et al., 2013a, 2016; Priyadarshana, 2016). Mean latitude of blue whale sightings was $5^{\circ} 50^{\prime} \mathrm{N}$ (range $5^{\circ} 43^{\prime}$ to $\left.5^{\circ} 56^{\prime} \mathrm{N}\right)$ i.e. roughly centred along the $1,000 \mathrm{~m}$ isobath, and in the westbound shipping lane (Fig. 3). There was no difference in mean latitude (i.e. distance offshore) in 2007-09 versus 2010-13 (i.e. before and after the expansion of commercial whale watching at Mirissa) (Table 4). However, blue whales were more latitudinally dispersed in $2010-2013\left(5^{\circ} 43^{\prime}\right.$ to $\left.5^{\circ} 56^{\prime} \mathrm{N}\right)$ than in $2007-2009\left(5^{\circ} 46^{\prime}\right.$ to $\left.5^{\circ} 53^{\prime} \mathrm{N}\right)$. The issue of disturbance by whale-watching vessels is discussed further below.

\section{Bryde's whale}

During this study there were five sightings of 'Bryde's whales' (B. edeni/brydei). The taxonomy of these whales is not yet resolved, but it is likely that there are two species within the northern Indian Ocean, including Sri Lanka: the larger offshore Bryde's whale (B. brydei), and the smaller inshore Eden's whale (B. edeni). These taxa are currently recognised as forms, ecotypes or subspecies, although they probably warrant full specific status (e.g. Sasaki et al., 2006; Yamada et al., 2006; Kershaw et al., 2013; Luksenburg et al., 2015). However, an outstanding issue is that the holotype of B. edeni (in Kolkata, India) has yet to be genetically typed. 


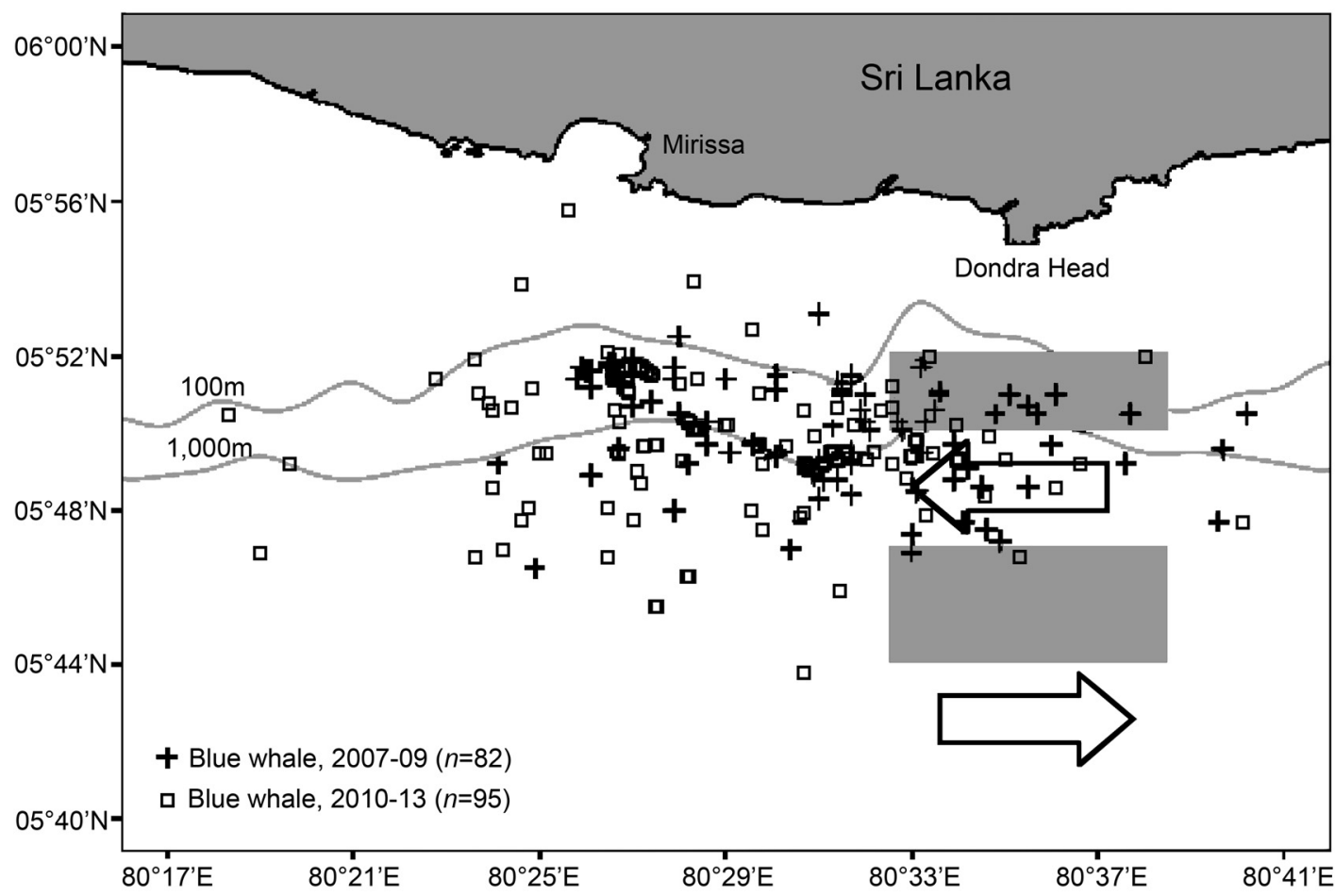

Fig. 3. Blue whales: distribution of sightings off the South coast of Sri Lanka during two time periods (2007-09 and 2010-13).

Table 4

Blue whale numbers, sightings rates and mean latitudes off Mirissa during two time periods (April only, excludes two days in March 2009).

\begin{tabular}{|c|c|c|c|}
\hline & $2007-09$ & $2010-13$ & $2007-13$ \\
\hline \multicolumn{4}{|l|}{ Sighting effort } \\
\hline No. days & 26 & 20 & 46 \\
\hline Mean latitude of boat positions & $5^{\circ} 50.9^{\prime} \mathrm{N}$ & $5^{\circ} 51.2^{\prime} \mathrm{N}$ & $5^{\circ} 51.0^{\prime} \mathrm{N}$ \\
\hline Mean longitude of boat positions & $80^{\circ} 30.2^{\prime} \mathrm{E}$ & $80^{\circ} 27.4 \mathrm{E}$ & $80^{\circ} 29.0^{\prime} \mathrm{E}$ \\
\hline \multicolumn{4}{|l|}{ Blue whales } \\
\hline No. encounters & 108 & 62 & 170 \\
\hline Encounters per day $($ mean $\pm 95 \% \mathrm{CI})$ & $4.2 \pm 0.8$ & $3.1 \pm 0.8$ & $3.7 \pm 0.6$ \\
\hline No. blue whales & 150 & 110 & 260 \\
\hline Blue whales per day $($ mean $\pm 95 \% \mathrm{CI})$ & $5.8 \pm 1.0$ & $5.5 \pm 1.1$ & $5.7 \pm 0.7$ \\
\hline Mean latitude $( \pm 95 \% \mathrm{CI})$ & $5^{\circ} 50.1^{\prime} \mathrm{N} \pm 0.3^{\prime}$ & $5^{\circ} 49.4^{\prime} \mathrm{N} \pm 0.5^{\prime}$ & $5^{\circ} 49.9^{\prime} \mathrm{N} \pm 0.2^{\prime}$ \\
\hline Latitude range & $5^{\circ} 46.9^{\prime}-5^{\circ} 53.1^{\prime} \mathrm{N}$ & $5^{\circ} 43.8^{\prime}-5^{\circ} 55.8^{\prime} \mathrm{N}$ & $5^{\circ} 43.8^{\prime}-5^{\circ} 55.8^{\prime} \mathrm{N}$ \\
\hline
\end{tabular}

Of the five animals sighted during this study, four were moderately large (about 11-15m) and appeared very much like whales seen in the Maldives which have been identified genetically as brydei-type (Kershaw et al., 2013). One animal (seen on 17 April 2012 at $5^{\circ} 50.6^{\prime} \mathrm{N}, 80^{\circ} 26.6^{\prime} \mathrm{E}$ ) was much smaller (about $6 \mathrm{~m}$ ). Some of its features were consistent with a brydei-type animal: it was dark coloured dorsally (apparently uniformly so); had a relatively large, upright, sickle-shaped dorsal fin; had a tall, thin, vertical blow; and did not fluke when diving. Other features were different: it appeared to have five ridges on its rostrum, which seemed somewhat narrow and pointed; it was of a size at which a brydei-type animal would likely still be a calf closely associated with its mother; and it moved particularly fast, faster than the larger brydei-type animals, just beneath the water surface. It was tentatively identified as edeni-type.

The identification of small baleen whales in Sri Lanka is problematic. There have been previous reports of strandings and sightings, mostly from the northwest coast, which have been identified as minke whales, B. acutorostrata (e.g. Deraniyagala, 1948; 1960; 1963; Ilangakoon, 2002; Bröker and Ilangakoon, 2008). This identification seems to have started with Deraniyagala (1948), who identified a baleen whale of $6.4 \mathrm{~m}$ length stranded in May 1937 at Mannar (northwest coast) as B. acutorostrata, based on a newspaper photograph (which could not be found in the National Archives in March 2014) and measurements sent by an informant. Deraniyagala (1960) subsequently identified that stranded animal (together with a second one of $7.9 \mathrm{~m}$ from near Jaffna in January 1954) as a 'southern little piked whale' (i.e. Antarctic minke whale) B. a. bonaerenis. Rice (1998) dismissed Deraniyagala's 'use of the name $B$. a. bonaerensis for a whale (which he did not examine) [as] arbitrary and unwarranted.' There may be some validity in that assessment, but the reason for Deraniyagala's choice of name possibly followed from his belief that many whales and other marine animals were entering Sri Lankan waters from the southern hemisphere (Deraniyagala, 1960; 1965). Furthermore the only other two subspecific names then available applied to minke whales from the North Atlantic and North Pacific, both of which seem even less likely to occur in Sri Lanka. Then in July 1962, another five small 
baleen whales $(8.5-10.7 \mathrm{~m})$ stranded on the northwest coast. Deraniyagala (1963) again does not seem to have inspected the strandings in person, but he did secure some specimens for the National Museum (including some multi-coloured yellow/white and grey/black baleen plates). These additional strandings convinced him that there was in fact a local 'tropical race' of minke whale, which he named as a new subspecies, B. a. thalmaha. Rice (1998) drily noted that this 'alleged subspecies... remains enigmatic; the unique color pattern of its baleen plates... if not aberrant, leaves doubt whether it is really a minke whale.' Intriguingly, Deraniyagala (1963) considered B. edeni (Anderson, 1879) to be a junior synonym of $B$. a. bonaerensis (Burmeister, 1867). Deraniyagala (1963) gave no justification for this decision, but he may have been following Gibson-Hill (1950). The identity of these small Sri Lankan whales remains in question, but one possibility is that they are indeed B. edeni. In support of this suggestion, a small baleen whale (estimated length about $12 \mathrm{~m}$ ) which stranded just across the Gulf of Mannar on the South Indian coast in August 2006 has been genetically identified as edeni-type (Jayasankar et al., 2006). Subsequently four further whales (two measured as $3.9 \mathrm{~m}$ and $9.6 \mathrm{~m}$ ) were genetically identified as edeni-type from strandings on the Kerala coast of southwest India (George et al., 2011; Bijukumar et al., 2012). To the best of our knowledge there have been no minke whales genetically identified from India or Sri Lanka so far. Furthermore, Kershaw et al. (2013) found that among 56 genetic samples from 'Bryde's' whales collected in the northern Indian Ocean (Oman, the Maldives and Bangladesh) there were 11 brydei-type and 45 edeni-type animals but no B. acutorostrata. Nor were there any Omura's whales, Balaenoptera omurai, in those samples, although this species has now been recorded from Sri Lanka with one sighting off Mirissa (de Vos, 2017) and another off Trincomalee (RCA and Nilantha Kodithuwakku, pers. obs. 7 April 2016).

\section{Sperm whale}

Sperm whale (Physeter macrocephalus) sightings were concentrated along $5^{\circ} 49^{\prime} \mathrm{N}$ (range $5^{\circ} 47^{\prime}$ to $5^{\circ} 51^{\prime} \mathrm{N}$ ), i.e. just deeper than the $1,000 \mathrm{~m}$ isobaths (Fig. 4). This is only slightly South of the mean latitude of blue whale sightings (but with much less variability), and again is within the westbound shipping lane. There was no obvious net movement along the coast: four groups were noted to be travelling East, and four groups West. However, sperm whales have been seen heading eastwards in large aggregations in March (AA, pers. obs.).

Mean group size was $11.2 \pm 1.8$, rather similar to the 12.8 reported by de Vos et al. (2012). Modal group size was 1012. Most individuals appeared to be mature females or immatures, being estimated at $\leq 10 \mathrm{~m}$ (although precise length estimations were not made). Only one individual was thought to be a mature male, because of its particularly large size (length uncertain but estimated to be $>12 \mathrm{~m}$ ). That was seen on 24 April 2011, the latest date on which observations were made. Remarkably, the only mature male sighted by Gordon (1989) was on 24 April 1984, again the last day of his observations.

\section{Short-finned pilot whale}

Three sightings of short-finned pilot whales (Globicephala macrorhynchus) were made on consecutive days (9-11 April 2009), all in the same general area (about $10-13 \mathrm{~km}$ off Dondra Head). These sightings may possibly have all been of the same group. Certainly, distinctive individuals, including a pale brown animal (presumed to be an adult female because it was accompanied by a calf, of normal colour) and another animal with no dorsal fin, were seen on both 10 and 11 April, although not on 9 April. On all three days the pilot whales were accompanied by common bottlenose dolphins (Tursiops truncatus), with about 200 bottlenose on 9 April and about 40-50 on 10 and 11 April.

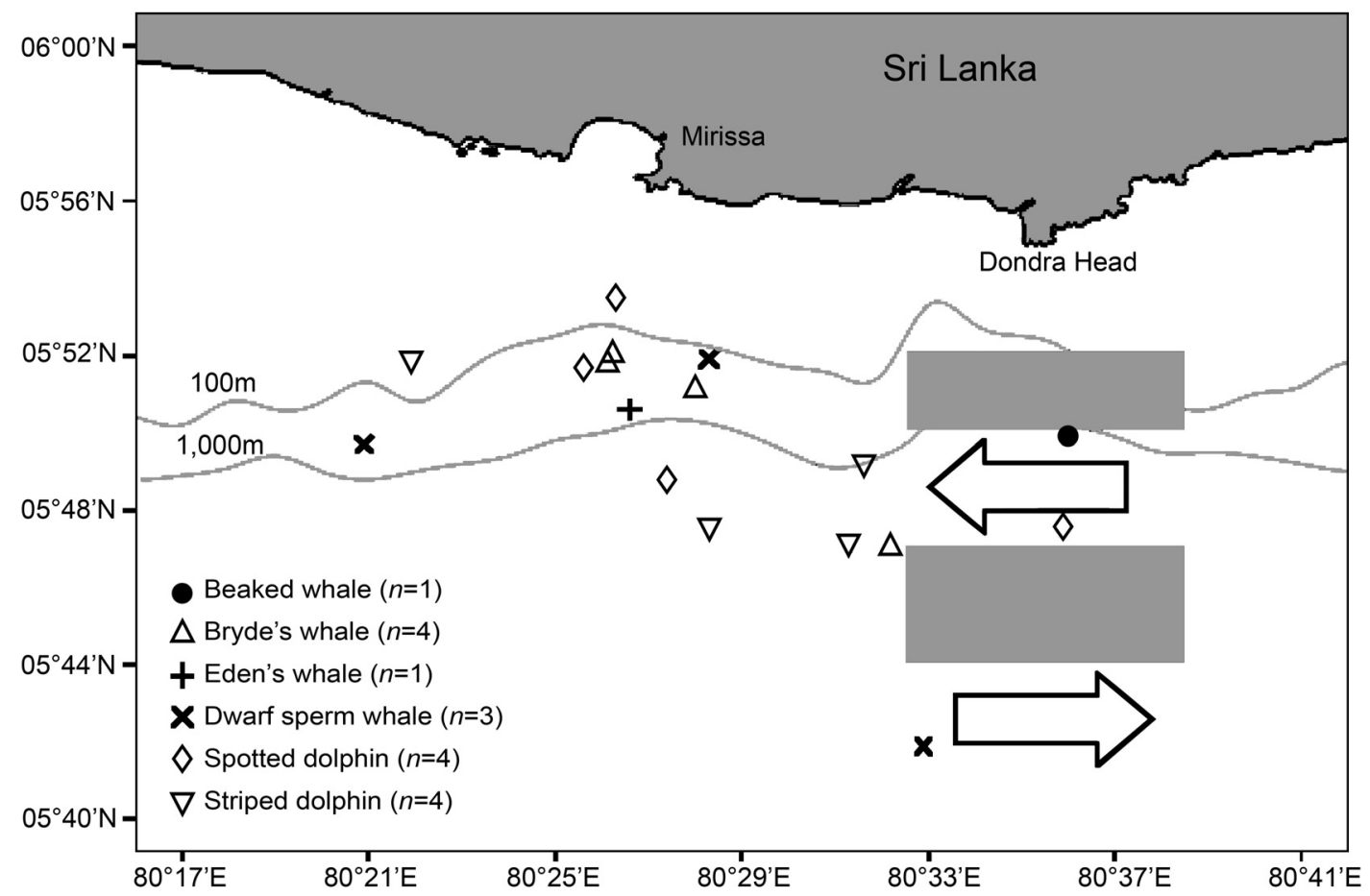

Fig. 4. Miscellaneous cetacean sightings off the South coast of Sri Lanka during 2007-2013. 
On 11 April Risso's dolphins (Grampus griseus) were also present. The Risso's were particularly active at the surface, breaching and tail-slapping. On that occasion, after some time the pilot whales moved towards the East at about 9-10 $\mathrm{km} \mathrm{h}^{-1}$, followed by the bottlenose dolphins. It seemed likely that this was an aggressive encounter, resulting in the displacement of the pilot whales, as has been documented elsewhere (Shane, 1995; Anderson, 2005).

\section{Bottlenose dolphin}

Two species of bottlenose dolphin were identified: common (Tursiops truncatus) and Indo-Pacific (Tursiops aduncus). Animals identified as T. truncatus appeared somewhat larger, with stubbier beaks; were often a darker and less uniform grey in dorsal colouration; were seen in close association with pilot whales on three occasions; occurred in larger schools (mean size 90.6); occurred more offshore (Fig. 5); and readily bowrode. Animals identified as T. aduncus appeared slightly smaller, with slightly longer beaks; had relatively large dorsal fins; were more uniformly and slightly paler grey in dorsal colouration; in one instance revealed ventral spotting; were never seen in association with other cetaceans; occurred in smaller schools (mean size 8.0); occurred more inshore (Fig. 5); and avoided our boat.

T. aduncus appears to have been formally recorded from Sri Lanka only recently (Kurihara and Oda, 2007; Martenstyn, 2013), although its presence is not unexpected. Whitehead (1989, p.61) observed bottlenose dolphins close to the coast of Sri Lanka which were 'smaller, less vocal and less demonstrative' than T. truncatus and which he considered might be T. aduncus. Ilangakoon (2002) recorded only $T$. truncatus among bottlenose dolphin bycatch, but did note the presence of 'both the coastal and offshore forms' and that 'mature animals may sometimes have dark spots on the pale ventral surface'; this is a characteristic of T. aduncus.
Sri Lanka is within the expected range of T. aduncus and is included in the general distribution maps of this species by Jefferson et al. (2008) and Reeves et al. (2002). On the other hand, the reports of T. aduncus from Sri Lankan waters by Afsal et al. (2011) require confirmation: they only recorded this species, not T. truncatus, despite most of their bottlenose dolphin records being from offshore.

\section{Spinner dolphin}

Spinner dolphins were the most abundant species recorded (Table 2), accounting for some $67 \%$ of all cetaceans sighted, by number of individuals. This agrees with previous studies, which have recorded high numbers of spinner dolphins in Sri Lankan waters (e.g. Leatherwood and Reeves, 1989; Dayaratne and Joseph, 1993; Ilangakoon, 2002), and indeed in the wider tropical Indian Ocean (e.g. Ballance and Pitman, 1998; Anderson, 2005).

Spinner dolphins were mostly sighted over the outer shelf, in roughly $100-200 \mathrm{~m}$ depth (Fig. 6). Mean latitude of sightings was $5^{\circ} 51.5^{\prime} \mathrm{N}$, which is $5 \mathrm{~km}$ North (inshore) of the mean latitude of sperm whale sightings. It is assumed that these spinner dolphins feed mainly at night off the edge of the continental slope, and come into relatively shallower shelf waters during the day, as is comparable to the situation in other areas (e.g. Anderson, 2005; Norris et al., 1994; Silva and Da Silva, 2009). Although these spinner dolphins are assumed to feed mainly at night, they clearly associate with tuna during the daytime. Eleven groups of spinner dolphins were accompanied by seabirds, in every case including bridled terns (Sterna anaethetus). Other birds recorded were flesh-footed shearwater (Puffinus carneipes), wedge-tailed shearwater (Puffinus pacificus), Persian shearwater (Puffinus persicus), lesser crested tern (Thalasseus bengalensis), common tern (Sterna hirundo), little tern (Sternula albifrons), whiskered tern (Chlidonias hybridus) and white-

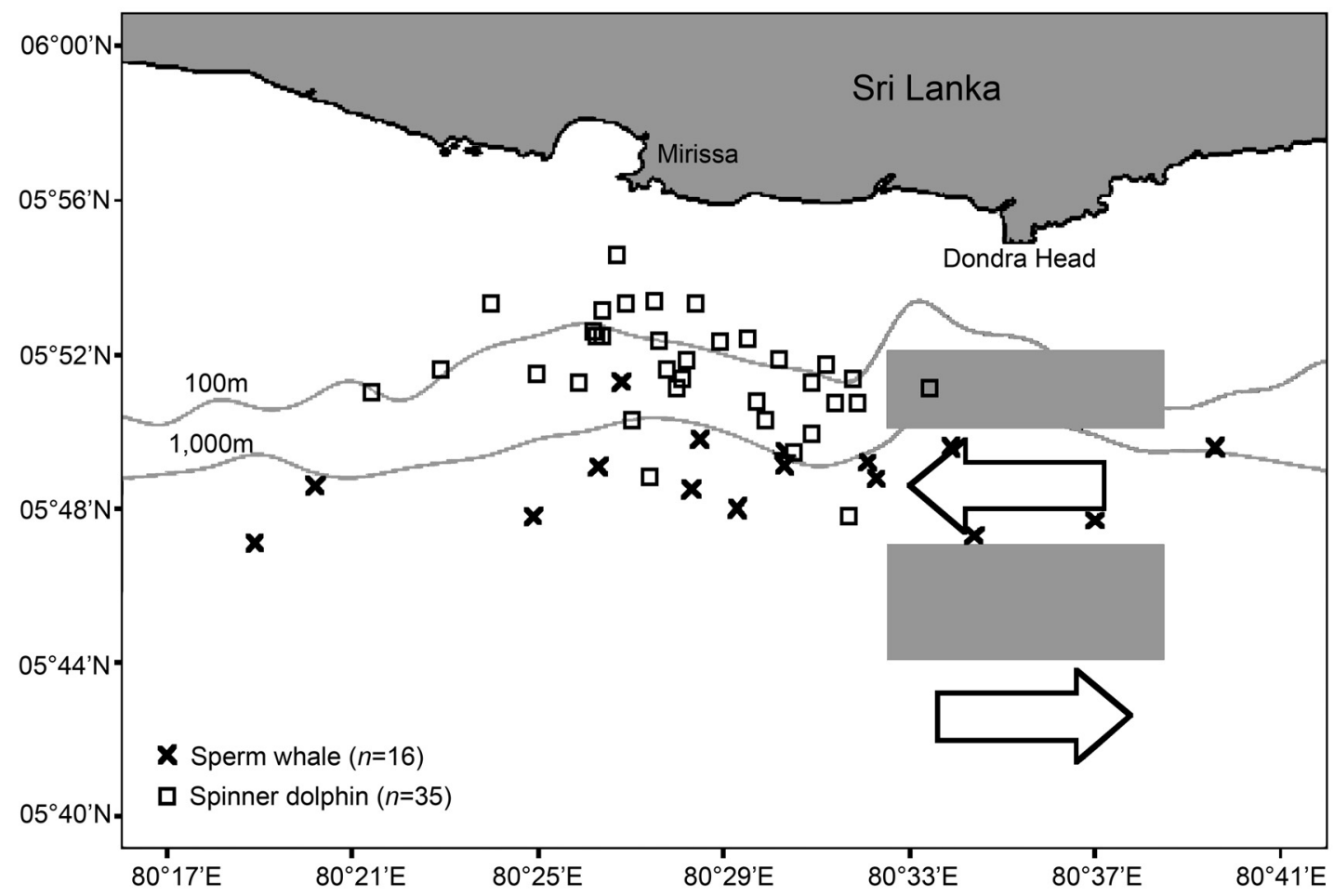

Fig. 5. Sperm whale and spinner dolphin sightings off the South coast of Sri Lanka during 2007-2013. 


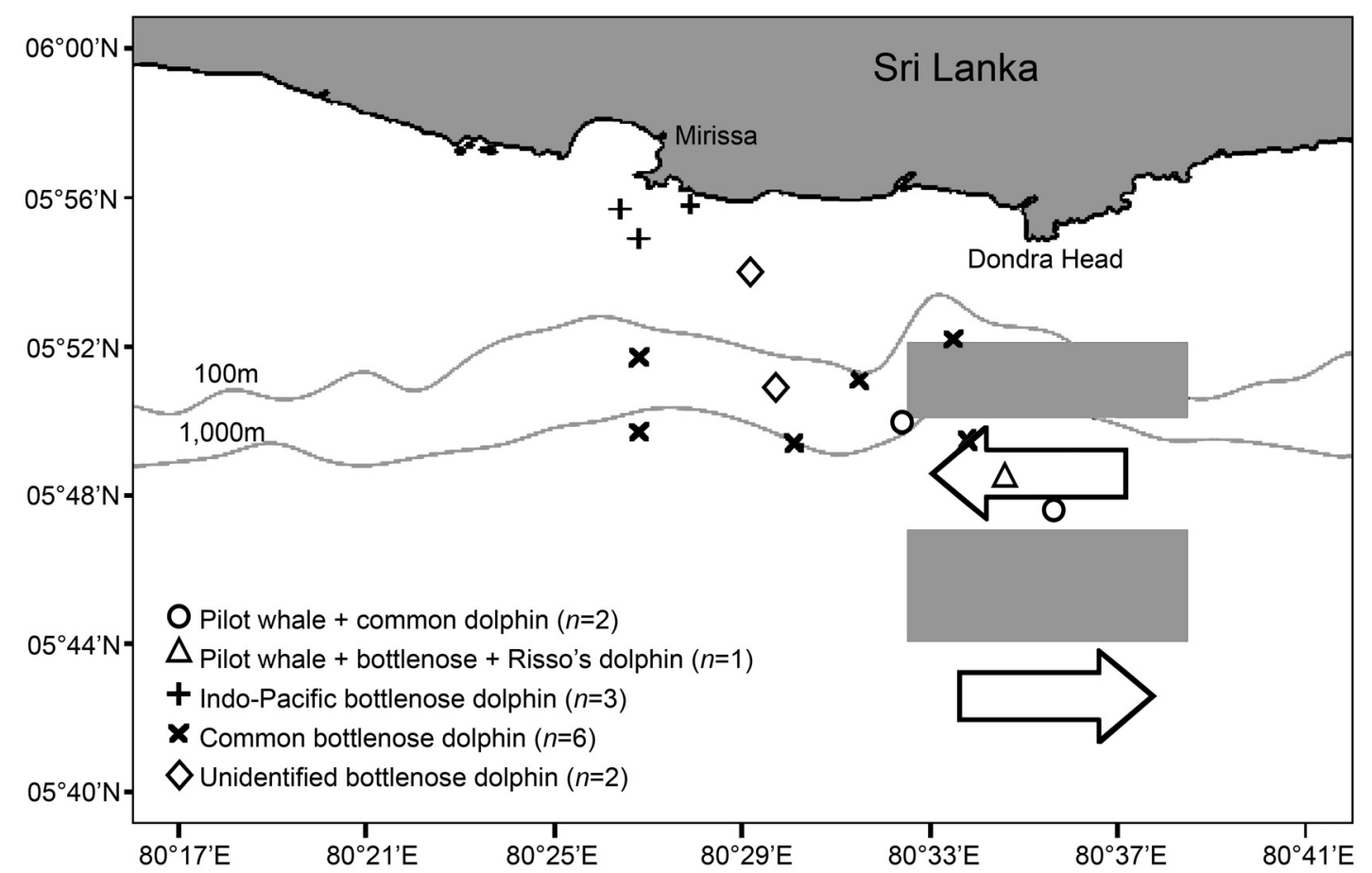

Fig. 6. Short-finned pilot whale, common bottlenose dolphin, Indo-Pacific bottlenose dolphin and Risso's dolphin sightings off the South coast of Sri Lanka during 2007-2013.

winged tern (Chlidonias leucopterus). In five of these 11 cases, tuna were seen, or fishing boats were present. The association of dolphins, particularly spinner dolphins, with tuna in Sri Lankan waters has been previously documented (e.g. Sivasubramaniam, 1970; De Silva and Boniface, 1991; Ilangakoon, 2002). More generally, the association of dolphins with yellowfin tuna (Thunnus albacares) is widespread in the tropical Indian Ocean (Anderson, 2014).

Of 19 groups of spinner dolphins for which direction of movement was recorded, 12 (63\%) were heading to the East and 7 to the West. Although the numbers are small, this might suggest a possible net movement of spinner dolphins eastwards around the South coast of Sri Lanka in April. If spinner dolphins are indeed moving eastwards in April (and perhaps westwards during the other inter-monsoon in October-November) then they might be more abundant on the East coast during the southwest monsoon, and on the West coast during the northeast monsoon. This is certainly consistent with published information, including the following:

(1) From a tuna fisheries aerial survey, Sivasubramaniam (1970) reported many dolphins with tuna (probably mostly spinner dolphins) off the East coast in July but not the West coast.

(2) From a 3-year (1984-86) survey of dolphin landings at Trincomalee fish market, Leatherwood and Reeves (1989, Table 12) presented data showing that spinner dolphins were on average landed twice as often during the southwest monsoon as during the northeast monsoon (13.0 spinners/mo. in April to October versus 6.8 spinners/mo. in November to March).

(3) Following a one-year national survey of dolphin landings, Dayaratne and Joseph (1993) reported that there were two clear peaks in dolphin (mostly spinner dolphin) landings on the South coast (mostly at Mirissa), in October-November and in April, which is consistent with two periods of movement around the South coast. While Dayaratne and Joseph (1993) attributed these peaks to an increase in deliberate taking of dolphins (by harpoon) during periods of low tuna catches, Ilangakoon et al. (2000a) suggested that harpooning of dolphins (by West coast fishermen) was not strongly affected by tuna catch, and therefore that landings reflected abundance.

(4) During a year-round survey off the northwest coast, Bröker and Ilangakoon (2008) observed spinner dolphins during the northeast monsoon, but not during the southwest monsoon.

(5) Spinner dolphins are much more abundant off Trincomalee on the northeast coast during the southwest monsoon than the northeast monsoon (Nilantha Kodithuwakku, naturalist at Trinco Blu hotel, pers. comm).

\section{Risso's dolphin}

There was just a single sighting of Risso's dolphin (Table 2; Fig. 5). This was surprising since this species has in the past been reported to be common in Sri Lankan waters (Alling, 1984; Leatherwood and Reeves, 1989; Ilangakoon, 2002). Although this single observation from a restricted area and time period is of limited interest by itself, combined with other sightings data from other areas and seasons (Table 5) it suggests a decline in the abundance of Risso's dolphins around the Sri Lankan coast over the past three decades. The comparatively high sightings rate noted by de Vos et al. (2012) in 2003 came from a remote area off the uninhabited southeast coast. Risso's dolphin bycatch landings show the same downward trend (Anderson, 2014). Sri Lanka has significant pelagic gillnet and harpoon fisheries. Kruse et al. 
(1991) identified Sri Lankan Risso's dolphins as being particularly vulnerable to overexploitation. They reviewed available catch and biological data and concluded that 'the current take of Risso's dolphins in the Sri Lankan drift gillnet fishery is not sustainable.' It appears that they may have been right.

\section{Fisheries interactions}

Sri Lanka is a major fishing nation. Studies in the 1980s and early 1990s demonstrated that large numbers of small cetaceans were being caught, both as bycatch in pelagic gillnets and as direct catch by harpoon (Alling, 1985; Ilangakoon, 1997; Ilangakoon et al., 2000a; 2000b; Leatherwood and Reeves, 1989; Prematunga et al., 1985). There was some controversy over the exact numbers being landed annually, although landings were clearly in the thousands. Leatherwood (1994) reworked earlier studies and conservatively estimated a catch of 8,042-11,821 dolphins per year during 1984-86. Dayaratne and Joseph (1993) estimated total annual landings of 5,181 dolphins during 1991-92. Reported tuna catches from the pelagic fisheries have increased roughly fourfold from about 20,000t per year in the 1980 s and early 1990 s to over 80,000 t per year recently, with gillnets remaining the main fishing gear (e.g. Perera et al., 2013; tuna catch data available from www.iotc.org). Although there has been no monitoring of cetacean landings since the mid-1990s, it is believed that some dolphin catching continues, despite cetaceans being legally protected (Ilangakoon, 2012a; Reeves et al., 2013).

The scarcity of Risso's dolphin sightings during this study highlights the possible impact these fisheries may be having on at least some cetacean populations. A recent global review (Jefferson et al., 2013) confirmed that Risso's dolphins range widely across inshore to oceanic habitats but have a strong preference for continental slope and outer shelf waters. The continental shelf and slope of Sri Lanka is contiguous with that of India. It seems likely that Risso's dolphin abundance has also been reduced in Indian waters, where there are also major gillnet fisheries which catch Risso's dolphins (e.g. Yousuf et al., 2009). Only four sightings of Risso's dolphins were reported from an extensive survey of Indian and adjacent seas (including Sri Lankan waters) conducted during 2003-2007 (Afsal et al., 2008). In contrast, the Maldives (which though adjacent to Sri Lanka and South India are not connected to their continental shelf, and do not have gillnet fisheries) have a much higher relative abundance of Risso's dolphins, of the order of $11-14 \%$ of sightings (Anderson, 2005; Clark et al., 2012; RCA, unpublished data, 2003-2016), which is comparable to what was seen off Sri Lanka in the 1980s (Table 5).

Unlike Risso's dolphins, spinner dolphins remain relatively abundant in Sri Lankan waters, despite large numbers having been taken by local fisheries (e.g. Dayaratne and Joseph, 1993). This suggests that large numbers may be continually entering Sri Lankan waters from elsewhere in the Indian Ocean; they are certainly abundant in the Maldives (Ballance et al., 2001; Anderson, 2005; Clark et al., 2012) and elsewhere in the Indian Ocean including the waters between the Maldives and Sri Lanka (Ballance and Pitman, 1998; RCA, pers. obs.). However, it seems unlikely that this situation can continue indefinitely, given the high and increasing extent of gillnet fishing and spinner dolphin bycatch in the wider Indian Ocean (Reeves et al., 2013; Anderson, 2014).

\section{Movements of whales and shipping}

The waters off southern Sri Lanka appear to be a migratory corridor for some cetacean species. The whole northern Indian Ocean is affected by the monsoons, experiencing twice-yearly reversals of ocean currents. This affects the distribution of phytoplankton, and thus also the distribution of zooplankton and micronekton (e.g. Longhurst, 1998). Any cetacean wanting to move between the Arabian Sea and the Bay of Bengal to take advantage of such seasonal productivity would have its passage blocked by the landmass of peninsular India and Sri Lanka. This may act like a giant inverted funnel, forcing animals to pass around the southern tip of Sri Lanka (the Palk Strait between Sri Lanka and India being too shallow for most species). The same land barrier ensures that one of the busiest shipping lanes in the world passes just off the southern coast of Sri Lanka. Ships travelling between the West (Europe, via the Suez Canal, as well as the Gulf) and East Asia, pass back and forth, just off Dondra Head. With the continental slope lying just 5-8km offshore, both whales and ships are visible from land.

Table 5

Sightings of Risso’s dolphins recorded during surveys around Sri Lanka, 1983-2013.

\begin{tabular}{|c|c|c|c|c|c|c|}
\hline \multirow[b]{2}{*}{ Date } & \multirow[b]{2}{*}{ Location } & \multicolumn{3}{|c|}{ No. of sightings } & \multirow[b]{2}{*}{ \% Risso’s } & \multirow[b]{2}{*}{ Source } \\
\hline & & Risso's & Cetaceans & Small cetaceans & & \\
\hline 1983 & NE coast & 2 & 26 & - & $7.7 \%$ & Leatherwood et al. (1984) \\
\hline 1994 & West coast & 0 & 25 & - & $0 \%$ & Ilangakoon et al. (2000a) \\
\hline 2003 & Sri Lanka & 6 & 76 & - & $7.9 \%$ & De Vos et al. (2012) \\
\hline $2004-05$ & NW coast & 0 & 33 & - & $0 \%$ & Bröker and Ilangakoon (2008) \\
\hline $2003-07$ & Sri Lanka & 1 & 86 & - & $1.2 \%$ & Afsal et al. (2008) \\
\hline $2008-09$ & South coast & 0 & 69 & - & $0 \%$ & Ilangakoon (2012a) \\
\hline $2007-13$ & South coast & 1 & 290 & - & $0.3 \%$ & This study \\
\hline $2010-12$ & $\mathrm{NE}$ coast & 0 & 215 & - & $0 \%$ & Nanayakkara et al. (2014) \\
\hline $1982-84$ & Sri Lanka & 29 & - & $170 *$ & $17.1 \%$ & Alling (1986) \\
\hline 2003 & Sri Lanka & 6 & - & 46 & $13.0 \%$ & De Vos et al. (2012) \\
\hline $2008-09$ & South coast & 0 & - & 48 & $0 \%$ & Ilangakoon (2012a) \\
\hline $2007-13$ & South coast & 1 & - & 82 & $1.2 \%$ & This study \\
\hline
\end{tabular}

*Note: Alling (1986) reported on cetaceans excluding large whales seen during the Tulip expedition. Small cetacean data from other studies (where $\mathrm{n}>40$ ) are presented for comparison. 
April, and also October-November, are the inter-monsoon periods, when ocean currents change. So too does the distribution of phytoplankton, and subsequently zooplankton. It is therefore to be expected that some cetaceans will change coasts at these times. As noted above, blue whales and spinner dolphins may both be moving around the South coast in April, but in opposite directions. Blue whales appear to be more abundant on the East coast of Sri Lanka during the northeast monsoon season (particularly February-April) and on the West coast during the southwest monsoon season (April-October) (Anderson et al., 2012). In contrast, the reverse seems to be true for spinner dolphins, which appear to prefer the downstream sides of the island (see above). There is an intriguing comparison to be made with the adjacent Maldives, where several species of cetacean also appear to 'swap sides' with the changing monsoons but in the opposite direction (RCA, unpublished data, 2000-16). In the case of Sri Lanka, the solid mass of the island deflects the monsoon currents, promoting upwelling on the upstream coast (and also along the South coast because currents from both East and West wrap around this shoreline). This, together with nutrient input from rivers flooded by rains coming in off the sea, promotes seasonally high primary productivity on the seasonally alternating upstream side as well as along the southern coast (e.g. Vinayachandran and Mathew, 2003; Vinayachandran et al., 2004; Yapa, 2009; de Vos et al., 2014a). The greatest numbers of blue whales might be expected on the more productive upstream side. In contrast, spinner dolphins, perhaps because of their small size, which may increase predation risk or competitive exclusion, appear to be most abundant on the apparently less productive downstream side (although the distribution and abundance of their mesopelagic prey is unknown). The situation is different in the Maldives. The Maldivian chain of coral atolls is a porous barrier, allowing the monsoon currents to pass through, and promoting upwelling in the process, which leads to a plankton bloom on the downstream side (Anderson et al., 2011). Therefore blue whales and other plankton feeders are more abundant on the downstream side (Anderson et al., 2011; 2012), while spinner dolphins seem to be most abundant on the apparently less productive upstream side (RCA, pers. obs.).

In the case of ships, one of the world's busiest shipping lanes passes just off Dondra Head. There is a traffic separation scheme in place with the inshore, westbound lane passing just outside the $1,000 \mathrm{~m}$ contour (Fig. 2). Much shipping therefore passes through waters where both blue whales and sperm whales are most abundant. Ship strikes are therefore inevitable (Ilangakoon, 2012c; de Vos et al., 2013a; Randage et al., 2014). There is a need to address this issue (perhaps by introducing speed restrictions within the existing shipping channels, or moving them further offshore) if such mortality is to be reduced (Priyadarshana et al., 2016). However, moving the shipping lanes offshore could open the way for gillnetting over the continental slope, with consequent greater cetacean mortality (Randage et al., 2014). In the meantime, concern has been expressed that the rate of ship strikes has increased as a result of whale watching from Mirissa disturbing blue whales and pushing them offshore into the shipping lanes (Ilangakoon, 2012c; 2013).

\section{Whale watching}

Since the discovery of large numbers of blue whales off the South coast of Sri Lanka, Mirissa has become a major centre for whale watching. Previously, the whales' presence, although well-known to local fishermen, was not more widely realised. In both 2007 and 2008, the vessel chartered for the excursions reported here was operating not as a whale watching boat but as part of a game-fishing and water-sports venture (set up in the wake of the 2004 tsunami by a philanthropic Belgian businessman resident in Sri Lanka). No other vessels were whale watching at that time. However, following widespread publicity starting in late 2008 (e.g. Wijeyeratne, 2008) whale watching activities have expanded rapidly (Fig. 7), as too has boat-based cetacean research (e.g. Ilangakoon, 2012a; 2012b; 2013; de Vos et al., 2013a; 2013b; 2014b; Randage et al., 2014; Priyadarshana et al., 2016).

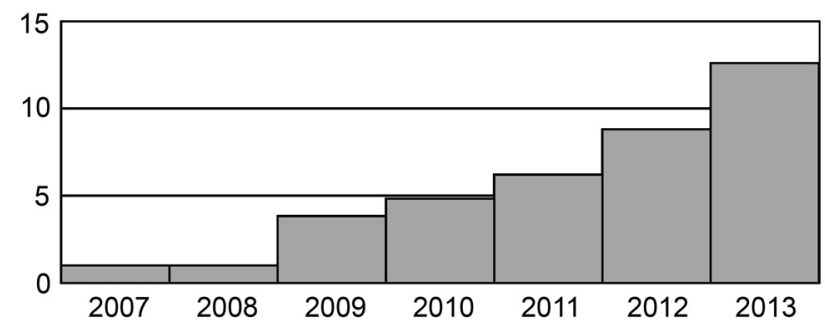

Fig. 7. Mean number of whale-watching boats per day, seen operating out of Mirissa, southern Sri Lanka, in April, 2007-2013.

While some boat operators do behave responsibly around the whales, others do not. Ilangakoon (2012c; 2013) has highlighted unregulated whale watching as a threat to blue whales off southern Sri Lanka. She further suggested that increased whale watching out of Mirissa was driving the blue whales further offshore, into the shipping lanes, with consequent increase in ship-strike mortality. The study reported here provides no evidence of blue whales being displaced offshore: the mean latitude of blue whale sightings was the same in the early years (2007-2009) as in the later years when many whale-watching boats were operating (2010-13) (Table 4). Randage et al. (2014) also present data which show no net movement offshore during three 'high' seasons (December-April), 2009-2010, 2010-2011 and 2011-2012. And while de Vos et al. (2014) did find an interannual shift in blue whale distribution offshore, that was related to interannual differences in oceanographic conditions. Furthermore, de Vos et al. (2013b) found no change in the frequency of fluking up before deep dives in the presence or absence of whale-watching vessels. Nevertheless, the data presented here do suggest that blue whales were more latitudinally dispersed during 2010-13 than in 2007-2009; one possible explanation could be disturbance by whale-watching vessels.

Blue whales were present over the continental slope, and in the shipping lanes, even in 2007-08, before the explosive growth of whale watching from Mirissa (Fig. 3). If blue whales are being disturbed by whale watching, then there is no obvious reason why they should not move along the continental slope, rather than offshore. One reason for the recent increase in numbers of blue whale carcasses being 
reported is probably the great increase in the number of observers, following the expansion of whale watching. In addition, over recent decades, the general increase in the volume and speed of international shipping passing southern Sri Lanka (Priyadarshana et al., 2016), together with the likely increase in blue whale numbers (assuming that the northern Indian Ocean population has largely recovered from whaling in the 1960s) may have contributed to an increase in the actual number of ship strikes.

Whatever the case, it is clear that both unregulated whale watching and ship strikes are causes of concern for blue whales and other cetacean species off the southern coast of Sri Lanka. At the same time, bycatch of cetaceans in gillnet and other fisheries is impacting several species. All of these issues need to be addressed if cetacean watching is to continue to be a profitable enterprise for the people of southern Sri Lanka and if the cetacean populations of the region are to be sustained.

\section{ACKNOWLEDGEMENTS}

This study was carried out under the auspices of the Whale and Dolphin Company, and all observations were made during the course of commercial whale-watching operations. We are most grateful to Mirissa Watersports and the captains and crew of Spirit of Dondra for their enthusiastic support and to Deepika Kumari; to the Jetwing Research Initiative and Gehan de Silva Wijeyeratne for assistance with accommodation in Sri Lanka in 2008 and 2009; to Nilantha Kodithuwakku and Buddika Dayarathne for helpful discussions; to Mohamed Shiham Adam for preparing the maps; and to Anouk Ilangakoon, another cetacean scientist who prefers to remain un-named, and two anonymous referees for comments on a draft of this paper.

\section{REFERENCES}

Afsal, V.V., Yousuf, K.S.S.M., Anoop, B., Annop, A.K., Kannan, P., Rajagopalan, M. and Vivekanandan, E. 2008. A note on cetacean distribution in the Indian EEZ and contiguous seas during 2003-07. J. Cetacean Res. Manage. 10(3):209-16.

Alling, A. 1985. Small cetacean entanglement: a case study of the incidental entrapment of cetaceans in Sri Lanka's gillnet fishery. Paper SC/37/SM5 presented to the IWC Scientific Committee, June 1985 (unpublished). 8pp. [Paper available from the Office of this Journal]

Alling, A. 1986. Records of Odontocetes in the northern Indian Ocean (1981-1982) and off the coast of Sri Lanka (1982-1984). J. Bombay Nat. Hist. Soc. 83:376-94.

Alling, A.K., Dorsey, E.M. and Gordon, J.C.D. 1991. Blue whales Balaenoptera musculus off the northeast coast of Sri Lanka: Distribution, feeding and individual identification. pp.247-58. In: S. Leatherwood and G.P. Donovan, (eds) Cetaceans and Cetacean Research in the Indian Ocean Sanctuary. United Nations Environment Programme Marine Mammal Technical Report No. 3, Nairobi, Kenya. 287pp.

Anderson, R.C. 2005. Observations of cetaceans in the Maldives, 1990 2002. J. Cetacean Res. Manage. 7(2):119-35.

Anderson, R.C. 2014. Cetaceans and tuna fisheries in the western and central Indian Ocean. IPNLF Technical Report 2:1-133. [Available at: www.ipnlf.org].

Anderson, R.C., Adam, M.S. and Goes, J.I. 2011. From monsoons to mantas: seasonal distribution of Manta alfredi in the Maldives. Fish. Oceanogr. 20:104-13.

Anderson, R.C., Shaan, A. and Waheed, Z. 1999. Records of cetacean 'strandings' from the Maldives. J. South Asian Nat. Hist. 4(2):187202

Anderson, R.C., Branch, T.A., Alagiyawadu, A., Baldwin, R. and Marsac, F. 2012 Seasonal distribution, movements and taxonomic status of blue whales (Balaenoptera musculus) in the northern Indian Ocean. J. Cetacean Res. Manage. 12(2):203-18.
Ballance, L.T. and Pitman, R.L.1998. Cetaceans of the western tropical Indian Ocean: distribution, relative abundance, and comparisons with cetacean communities of two other tropical ecosystems. Mar. Mamm. Sci. 14: 429-59

Ballance, L.T., Anderson, R.C., Pitman, R.L., Stafford, K., Shaan, A., Waheed, Z. and Brownell, R.L. 2001. Cetacean sightings around the Republic of the Maldives, April 1998. J. Cetacean Res. Manage. 3(2):213-18

Berzin, A.A. 2008. The truth about Soviet whaling. Mar. Fish. Rev. 70(2):4 59.

Bijukumar, A., Jijith, S.S., Kumar, U.S. and George, S. 2012. DNA barcoding of the Bryde's Whale Balaenoptera edeni Anderson (Cetacea: Balaenopteridae) washed ashore along Kerala coast, India. J. Threatened Taxa 4(3):2436-43.

Branch T.A., Matuoka, K. and Miyashita, T. 2004. Evidence for increases in Antarctic blue whales based on Bayesian modelling. Mar. Mamm. Sci. 20:726-54.

Bröker, K.C.A. and Ilangakoon, A. 2008. Occurrence and conservation needs of cetaceans in and around the Bar Reef Marine Sanctuary, Sri Lanka. Oryx 42(2):286-91.

Brownell, R.L. 1995. Japanese and Soviet exploitation of pygmy blue whales. IBI Reports 5:25-9.

Clapham, P. and Ivashchenko, Y. 2009. A whale of a deception. Mar. Fish. Rev. 71:44-52.

Clark, R.A., Johnson, C.M., Johnson, G., Payne, R., Kerr, I., Anderson, R.C., Sattar, S.A., Godard, C.A.J. and Madsen, P.T. 2012. Cetacean sightings and acoustic detections in the offshore waters of the Maldives during the northeast monsoon seasons of 2003 and 2004. J. Cetacean Res. Manage. 12(1):227-34.

Dayaratne, P. and Joseph, L. 1993. A study on dolphin catches in Sri Lanka. Bay of Bengal Programme Report 56:1-43.

Deraniyagala, P.E.P. 1948. Some mystacetid whales from Ceylon. Spolia Zeylanica 25:61-3.

Deraniyagala, P.E.P. 1960. Some southern temperate zone snakes, birds and whales that enter the Ceylon area (Part I). Spolia Zeylanica 29:79-85.

Deraniyagala, P.E.P. 1963b. Mass mortality of the new subspecies of little piked whale Balaenoptera acutorostrata thalmaha and a new beaked whale Mesoplodon hotaula from Ceylon. Spolia Zeylanica 30:79-84.

Deraniyagala, P.E.P. 1965. Comparison of Mesoplodon hotaula Deraniyagala with Ziphius cavirostris indicus (van Beneden). Spolia Zeylanica 30:3-12.

De Silva, J. and Boniface, B. 1991. The study of the handline fishery on the west coast of Sri Lanka with special reference to the use of dolphin for locating yellowfin tuna (Thunnus albacares). IPTP Coll. Vol. Work. Docs. 4:314-24.

De Silva, P.H.D.H. 1987. Cetaceans (whales, dolphins and porpoises) recorded off Sri Lanka, India, from the Arabian Sea and Gulf, Gulf of Aden and from the Red Sea. J. Bombay Nat. Hist Soc. 84:505-25.

de Vos, A., Clark, R., Johnson, C., Johnson, G., Kerr, I., Payne, R. and Madsen, P.T. 2012. Cetacean sightings and acoustic detections in the offshore waters of Sri Lanka: March-June 2003. J. Cetacean Res. Manage. 12(2):185-93.

de Vos, A., Wu, T. and Brownell, R.L., Jr. 2013a. Recent blue whale deaths due to ship strikes around Sri Lanka. Paper SC/65a/HIM03 presented to the IWC Scientific Committee, June 2013, Jeju Island, Republic of Korea (unpublished). 8pp. [Paper available from the Office of this Journal].

de Vos, A., Christiansen, F., Harcourt, R.G. and Pattiaratchi, C.B. 2013b. Surfacing characteristics and diving behaviour of blue whales in $\mathrm{Sri}$ Lankan waters. J. Exp. Mar. Biol. Ecol. 449:149-53.

de Vos, A., Pattiaratchi, C.B. and Wijeratne, E.M.S. 2014a. Surface circulation and upwelling patterns around Sri Lanka. Biogeosciences 11:5909-30.

de Vos, A., Pattiaratchi, C.B. and Harcourt, R.G. 2014b. Inter-annual variability in blue whale distribution off southern Sri Lanka between 2011 and 2012. J. Mar. Sci. Eng. 2(3):534-50.

de Vos, A., Brownell, R.L., Jr, Tershy, B.R. and Croll, D.A. 2016. Anthropogenic threats and conservation needs of blue whales, Balaenoptera musculus indica, around Sri Lanka. J. Mar. Biol. 2016 (8420846):1-12.

de Vos, A. 2017. First record of Omura's whale, Balaenoptera omurai, in Sri Lankan waters. Mar. Biodivers. Rec. 10(1):1-18.

Doniol-Valcroze, T., Lesage, V., Giard, J. and Michaud, R. 2011. Optimal foraging theory predicts diving and feeding strategies of the largest marine predator. Behav. Ecol. 22:880-8.

Fein, J.S. and Stephens, P.L. 1987. Monsoons. Wiley, New York. 631pp.

Fernando, H.F. 1912. Whales washed ashore on the coast of Ceylon from 1889 to 1910. Spolia Zeylanica 8(29):52-4.

George, S., Meenkashi, K., and Bijukumar, A. 2011. Molecular taxonomy of marine mammals stranded along Kerala coast, India. Curr. Sci.100(1):117-20. 
Gibson-Hill, C.A. 1950. A note on the rorquals (Balaenoptera spp.). J. Bombay Nat. Hist. Soc. 49(1):14-19.

Gordon, J.C.D. 1987. Sperm whale groups and social behaviour observed off Sri Lanka. Rep. Int. Whal. Commn 37:205-217.

Gordon, J.C.D. 1991. The World Wildlife Fund's Indian Ocean sperm whale project: an example of cetacean research within the Indian Ocean Sanctuary. pp.219-239. In: S. Leatherwood and G.P. Donovan (eds). Cetaceans and Cetacean Research in the Indian Ocean Sanctuary. United Nations Environment Programme Marine Mammal Technical Report No. 3, Nairobi, Kenya. 287pp.

Hydrographic Office. 2007. West Coast of India Pilot. 15th Edn. Hydrographic Office, Taunton. 354pp.

Ilangakoon, A. 1997. Species composition, seasonal variation, sex ratio and body length of small cetaceans caught off the west, south-west and south coasts of Sri Lanka. J. Bombay Nat. Hist. Soc. 94:298-306.

Ilangakoon, A.D., Ratnasooriya, W.D. and Miththapala, S. 2000a. Species diversity, seasonal variation and capture method of small cetaceans on the west coast of Sri Lanka. Vidyodaya J. Sci. 9:37-52.

Ilangakoon, A.D., Miththapala, S. and Ratnasooriya, W.D. 2000b. Sex ratio and size range of small cetaceans in the fisheries catch on the west coast of Sri Lanka. Vidyodaya J. Sci. 9:25-35.

Ilangakoon, A.D. 2002. Whales and Dolphins Sri Lanka. WHT Publications, Colombo. 99pp.

Ilangakoon, A.D. 2012a. A review of cetacean research and conservation in Sri Lanka. J. Cetacean Res. Manage. 12(2):177-83.

Ilangakoon, A.D. 2012b. Cetacean diversity and mixed-species associations off southern Sri Lanka. pp. 23-28. In: Proceedings of the 7th International Symposium on SEASTAR2000 and Asian Bio-logging Science (The 11th SEASTAR2000 workshop). [Available at https://repository.kulib. kyoto-u.ac.jp/dspace/handle/2433/154047].

Ilangakoon. A.D. 2012c. Exploring anthropogenic activities that threaten endangered blue whales (Balaenoptera musculus) off Sri Lanka. J. Mar Anim. Ecol. 5:3-7.

Ilangakoon, A.D. 2013. Impacts of whale-watching on blue whales (Balaenoptera musculus) off southern Sri Lanka. pp. 45-50. In: Proceedings of the Design Symposium on Conservation of Ecosystems. (The 12th SEASTAR2000 workshop). [Available at https://repository. kulib.kyoto-u.ac.jp/dspace/bitstream/2433/176191/1/12thseastar_045.pdf].

Jayasankar, P., Anoop, B., Afsal, V.V. and Rajagopalan, M. 2006. Species and sex of two baleen whales identified from their skin tissues using molecular approach. Mar. Fish. Inf. Serv., Tech. and Ext. Ser. 190:1617.

Jefferson, T.A., Weir, C.R., Anderson, R.C., Ballance, L.T., Kenney, R.D. and Kiszka, J. 2013. Global patterns of distribution, density, and group size for Risso's dolphin (Grampus griseus): A review and critical evaluation. Mammal Review 44:56-68.

Joseph, L. and Sideek, M.S.M. 1985. Threat to dolphins and small whales from commercial fisheries. Paper presented to the Annual Meeting of the Sri Lankan Association for the Advancement of Science, Colombo, October 1985 (unpublished). 14pp.

Kershaw, F., Leslie, M.S., Collins, T., Mansur, R.M., Smith, B.D., Minton, G., Baldwin, R., Leduc, R.G., Anderson, R.C., R.L. Brownell Jr and Rosenbaum, H.C. (2013) Population differentiation of 2 forms of Bryde's Whales in the Indian and Pacific Oceans. J. Heredity 104:755-64.

Krey, J. 1973. Primary production in the Indian Ocean I. pp. 115-130. In: B. Zeitzschel (ed.) Biology of the Indian Ocean. Springer-Verlag, Berlin \& Chapman Hall, London. 549pp.

Kruse, S., Leatherwood S., Prematunga, W.P., Mendes, C. and Gamage, A. 1991. Records of Risso's dolphins, Grampus griseus, in the Indian Ocean, 1891-1986. UNEP Mar. Mamm. Tech. Rep. 3:67-78.

Kurihara, N. and Oda, S.I. 2007. Cranial variation in bottlenose dolphins Tursiops spp. from the Indian and western Pacific Oceans: additional evidence for two species. Acta Theriologica 52:403-18.

Leatherwood, S. 1994 Report of the workshop on mortality in passive fishing nets and traps. Annex D. Re-estimation of incidental cetacean catches in Sri Lanka. Rep. Int. Whal. Commn (special issue 15):64-5.

Leatherwood, S. and Reeves, R.R. 1989. Marine mammal research and conservation in Sri Lanka 1985-1986. UNEP Mar. Mamm. Tech. Rep. $1: 1-138$

Leatherwood, S., Peters, C.B., Santerre, R., Santerre, M. and Clarke, J.T. 1984. Observations of cetaceans in the northern Indian Ocean Sanctuary, November 1980-May 1983. Rep. Int. Whal. Commn 34:509-20.

Longhurst, A.R. 1998. Ecological Geography of the Sea. Academic Press, London. 420pp.

Luksenburg, J.A., Henriquez, A. and Sangster, G., 2015. Molecular and morphological evidence for the subspecific identity of Bryde's whales in the southern Caribbean. Mar. Mamm. Sci. 31(4):1568-79.

Martenstyn, H. 2013. Out of the Blue: A Guide to the Marine Mammals of Sri Lanka, Southern India and the Maldives. Howard Martenstyn, Colombo. 256pp.
Mikhalev, Y.A. 1996. Pygmy blue whales of the northern-western Indian Ocean. Paper SC/48/SH30 presented to IWC Scientific Committee, June 1996, Aberdeen, UK (unpublished). 30pp. [Available from the Office of this Journal].

Mikhalev, Y.A. 2000. Whaling in the Arabian Sea by the whaling fleets Slava and Sovetskaya Ukraina. pp.141-81. In: Yablokov, A.V., Zemsky, V.A. and Tormosov, D.D. (eds). Soviet Whaling Data (1949-1979). Centre for Russian Environmental Policy, Moscow. 408pp.

Molinari, R.L., Olsen, D. and Reverdin, G. 1990. Surface current distribution in the tropical Indian Ocean derived from compilations of surface buoy trajectories. J. Geophys. Res. 95(C):7217-38.

Nanayakkara, R.P., Herath, J. and de Mel, R.K. 2014. Cetacean presence in the Trincomalee Bay and adjacent waters, Sri Lanka. J. Mar. Biol. 2014, Article 819263:1-8. [Available at: dx.doi.org/10.1155/2014/819263].

Norris, K.S., Würsig, B., Wells, R.S. and Würsig, M. 1994. The Hawaiian Spinner Dolphin. University of California Press, Berkeley, Los Angeles and London. 408pp

Pant, G.B. and Kumar, K.R. 1997. Climates of South Asia. John Wiley \& Sons, Chichester. 320pp.

Perera, H.A.C.C., Haputhanthri, S.S.K. and Bandaranayake, K.H.K. 2013. A review on oceanic tuna fishery in Sri Lanka and estimation of the length-weight relationships for yellowfin tuna and bigeye tuna. IOTC2013-WPTT15-16. (Available at: www.iotc.org).

Perrin, W.F., Mead, J.G. and Brownell Jr, R.L. 2010. Review of the evidence used in the description of currently recognized cetacean subspecies. NMFS Technical Memorandum NOAA-TM-NMFS-SWFSC-450:135 .

Prematunga, W.P., Alling, A. and Leatherwood, S. 1985. Species composition of small cetacean bycatches in gillnets off Trincomalee, Sri Lanka, January 1984 through April 1985. Paper SC/37/SM9 presented to the IWC Scientific Committee, June 1985 (unpublished). 9pp. [Paper available from the Office of this Journal].

Priyadarshana, T., Randage, S. M., Alling, A., Calderan, S., Gordon, J., Leaper, R. and Porter, L. 2016. Distribution patterns of blue whale (Balaenoptera musculus) and shipping off southern Sri Lanka. Regional Studies in Marine Science 3:181-88.

Randage, S.M., Alling, A. Currier, K. and Heywood, E. 2014. Review of the Sri Lanka blue whale (Balaenoptera musculus) with observations on its distribution in the shipping lane. J. Cetacean Res. Manage. 14(1): 43-

Reeves, R.R., McClellan, K. and Werner, T.B. 2013. Marine mammal bycatch in gillnet and other entangling net fisheries, 1990 to 2011. Endang. Species Res. 20:71-97.

Sasaki, T., Nikaido, M., Wada, S., Yamada, T.K., Cao, Y., Hasegawa, M. and Okada, N. 2006. Balaenoptera omurai is a newly discovered baleen whale that represents an ancient evolutionary lineage. Mol. Phylogen. Evol. 41:40-52.

Schott, F. and McCreary, J.P. 2001. The monsoon circulation of the Indian Ocean. Prog. Oceanogr. 51:1-123.

Shane, S.H. 1995. Relationship between pilot whales and Risso's dolphins at Santa Catalina Island, California, USA. Mar. Ecol. Prog. Ser. 123:511.

Shankar, D., Vinaychandran, P.N. and Unnikrishnan, A.S. 2002. The monsoon currents in the north Indian Ocean. Prog. Oceanogr. 52:63120 .

Shirihai, H. and Jarrett, B. 2006. Whales, Dolphins and Seals: A Field Guide to the Marine Mammals of the World. A\&C Black, London. 384pp.

Silva, F.J.d.L. and Da Silva, J.M. Jr. (2009), Circadian and seasonal rhythms in the behavior of spinner dolphins (Stenella longirostris). Mar. Mam. Sci. 25:176-86.

Sivasubramaniam, K. 1970. An aerial survey for surface tuna resources in the seas around Ceylon. Bull. Fish. Res. Station, Ceylon 21:17.

Vinayachandran, P.N. and Mathew, S. 2003. Phytoplankton bloom in the Bay of Bengal during the northeast monsoon and its intensification by cyclones. Geophysical Res. Lett. 30(11). [Available at: https://doi.org/ 10.1029/2002GL016717].

Vinayachandran, P.N., Chauhan, P., Mohan, M. and Nayak, S. 2004. Biological response of the sea around Sri Lanka to summer monsoon. Geophysical Res. Lett. 31(1). [Available at: https://doi.org/10.1029/ 2003GL018533].

Vinayachandran, P.N., Kagimoto, T., Masumoto, Y., Chauhan, P., Nayak, S.R. and Yamagata, T. 2005. Bifurcation of the East India Coastal Current east of Sri Lanka. Geophysical Res. Lett. 32(15). [Available at: https://doi.org/10.1029/2005GL022864].

Whitehead, H. 1983. Baleen whales off Sri Lanka. Loris 15:176-81.

Whitehead, H. 1989. Voyage to the Whales. Robert Hale, London. xi+195pp.

Wijeyeratne, G.d.S. 2008. Best for blue. Serendib, Nov. 2008:42-5.

Wyrtki, K. 1973. Physical oceanography of the Indian Ocean. pp. 18-36. In: B. Zeitzschel (ed.) Biology of the Indian Ocean. Springer-Verlag, Berlin \& Chapman Hall, London. 549pp. 
Yablokov, A.V. 1994. Validity of Soviet whaling data. Nature 367(6,459): 108

Yamada, T.K., Chou, L.S., Chantrapornsyl, S., Adulyanukosol, K., Chakravarti, S.K., Oishi, M., Wada, S., Yao, C.J., Kakuda, T., Tajima, Y. and Arai, K. 2006. Middle-sized balaenopterid whale specimens (Cetacea: Balaenopteridae) preserved at several institutions in Taiwan, Thailand, and India. Mem. Nat. Sci. Mus. Tokyo 44:1-10.

Yapa, K.K.A.S. 2009. Upwelling phenomena in the southern coastal waters of Sri Lanka during southwest monsoon period as seen from MODIS. Sri Lanka J. Physics, 10:7-15.
Yousuf, K.S.S.M., Anoop, A.K., Anoop, B., Afsal, V.V., Vivekanandan, E., Kumarran, R.P., Rajagopalan, M., Krishnakumar, P.K. and Jayasankar, P. 2009. Observations on incidental catch of cetaceans in three landing centres along the Indian coast. Mar. Biodivers. Rec. 2. [Available at: https://dx.doi.org/10.1017/S175526720900075X].

Zemsky, V.A. and Sazhinov, E.G. 1994. Distribution and current abundance of the pygmy blue whales. SWFSC Admin. Rep. No. LJ-94-02: 17pp. [Originally in Russian with English summary. Translated in 1994 as above from 'Arsen'ev',VA (ed). 1982, Marine Mammals: Collected Papers', VNIRO, Moscow. pp. 53-70]. 